\title{
Protocol Keyword
}

National Cancer Institute

\section{Source}

National Cancer Institute. Protocol Keyword. NCI Thesaurus. Code C126062.

A word or small set of words designed to convey the subject of a clinical study. 